\title{
窒素を含屯 $\mathrm{TiC}-\mathrm{Mo}_{2} \mathrm{C}-\mathrm{Ni}$ 合金の高温強度 ${ }^{*}$
}

\author{
鈴木 寿**，林宏 爾***， \\ 松原秀 彰**, 徳本 啓**
}

\begin{abstract}
Hisashi Suzuki, Koji Hayashi, Hideaki Matsubara and Kei Tokumoto: High Temperature Strength of $\mathrm{TiC}-\mathrm{Mo}_{2} \mathrm{C}-\mathrm{Ni}$ Alloys Containing Nitrogen.

The strength and deformation characteristics of nitrogen contained $\mathrm{TiC}-\mathrm{Mo}_{2} \mathrm{C}-\mathrm{Ni}$ alloys were mainly studied at $1273 \mathrm{~K}$. The TiC-Mog $\mathrm{C}-\mathrm{Ni}, \mathrm{TiC}_{0.7} \mathrm{~N}_{0.3}-\mathrm{Mo}_{2} \mathrm{G}-\mathrm{Ni}$ and $\mathrm{TiC}_{0.5} \mathrm{~N}_{0.5}-\mathrm{Mo}_{2} \mathrm{C}-\mathrm{Ni}$ alloys with different carbon and $\mathrm{Mo}_{2} \mathrm{C}$ contents were used as specimens.

In usual bending tests, the deformation was suppressed and transverse-rupture strength increased with increasing nitrogen, carbon and $\mathrm{Mo}_{2} \mathrm{C}$ contents of the alloy. In creep bending tests, the suppression of deformation and an increase in creep strength were observed with increasing nitrogen and $\mathrm{Mo}_{2} \mathrm{C}$ contents of the alloy. The improvement of T.R.S. and creep strength was markedly observed, in particular, in the alloys containing nitrogen, and clearly related to the decreased grain size of carbonitride and the increased molybdenum content in binder it was phase, respectively.
\end{abstract}

(Received June 28, 1982)

\section{I 緒言}

最近, 我国では咥素 $(\mathrm{N})$ 添加の $\mathrm{TiC}-\mathrm{Mo}_{2} \mathrm{C}-\mathrm{Ni}$ 系 合金（サーメット）が切削工具用材料として広く用いら れつつあるが，この理由は $\mathrm{N}$ 添加により室温強度 ${ }^{1,22}$,

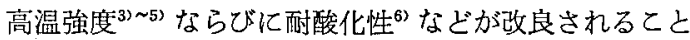
にあると思われる，しかし高温強度についての既報3,4 の結果は，試料中の $\mathrm{N}$ 量㧍よび $\mathrm{Mo}_{2} \mathrm{C}$ 量を変化させて いないし，N添加は TiN の形で行っている（ての場合 は TiN が組織中に一部残留) ので，さらに詳しい検討 が必要であると考えられた． $\mathrm{TiC}-\mathrm{Mo}_{2} \mathrm{C}-\mathrm{Ni}$ 合金にNを 添加すると，切削時のノーズだれが抑えられるとする Moskowitz ら5の試料にも TiN が添加されている.よ って本研究では $\mathrm{TiC}$ と $\mathrm{TiN}$ の固溶体である $\mathrm{Ti}(\mathrm{C}, \mathrm{N})$ 粉末を用いて作った $\mathrm{Ti}(\mathrm{C}, \mathrm{N})-\mathrm{Mo}_{2} \mathrm{C}-\mathrm{Ni}$ 合金を対象に， $1273 \mathrm{~K}$ における高温強度を詳しく調べた。とてでN無 添加の $\mathrm{TiC}-\mathrm{Mo}_{2} \mathrm{C}-\mathrm{Ni}$ 合金を比較試料とした。

\section{II＼cjkstart試料調製および実験方法}

市眅の $\mathrm{TiC}$ (粒度は $2.6 \mu \mathrm{m}), \mathrm{TiC}_{0.7} \mathrm{~N}_{0.3}(1.2 \mu \mathrm{m})$, $\mathrm{TiC}_{0.5} \mathrm{~N}_{0.5}(1.2 \mu \mathrm{m}), \mathrm{Mo}_{2} \mathrm{C}(3.6 \mu \mathrm{m}), \mathrm{Ni}(2.7 \mu \mathrm{m})$ 粉 末を用いて, 混合, 乾燥, 成形をへて, (1623〜1873) K $\times 3.6 \mathrm{ks}$ の真空焼結（真空度 $6.7 \mathrm{~Pa}$ ）により， $\mathrm{TiC}$ (11 27)\% $\mathrm{Mo}_{2} \mathrm{C}-(24 \sim 25) \% \mathrm{Ni}, \mathrm{TiC}_{0.7} \mathrm{~N}_{0.3}-(11 \sim 27) \%$ $\mathrm{Mo}_{2} \mathrm{C}-(24 \sim 25) \% \mathrm{Ni}, \mathrm{TiC}_{0.5} \mathrm{~N}_{0.5}-19 \% \mathrm{Mo}_{2} \mathrm{C}-23 \% \mathrm{Ni}$ の 2 相合金 ${ }^{2}$ （以下それぞれ $\mathrm{TiC}, \mathrm{TiC}_{0.7} \mathrm{~N}_{0.3}, \mathrm{TiC}_{0.5} \mathrm{~N}_{0.5}$
合金と呼ぶ****) を作った。どの合金む合金炭素量を変 化させたが，結合相の体積率はすべて $16.4 \%$ 一定とし た.

焼結後，各試料をダイヤモンド・ホィールで研削し， JIS 試片とした後, $1273 \mathrm{~K}$ におりる抗折試験, 短時間 曲げクリープ武験などに供した．また抗折試験はクロス ヘッド・スピード, $8.3 \times 10^{-6} \mathrm{~m} / \mathrm{s}$, クリープ試験は負荷 応力, 0.3 および $0.4 \mathrm{GPa}$ 下で行ない，各試料の抗折力 $\left(\sigma_{m}\right)$, 荷重 $(P)$-たわみ $(d)$ 曲線, クリープ曲線などを求 めた．ここで試験温度を $1273 \mathrm{~K}$ としたのは，本系合金 を切削工具として用いる場合，刃先温度は約 $1273 \mathrm{~K}$ に あ上昇するので，とのような高温における合金の強度が とくに重要と思われるからである。

他方，各試料の炭化物または炭窒化物の平均粒度を求 めた。 それには SEM 組織と Fullman の式”とを用い た。また結合相中の $\mathrm{Ti}$ および Mo 固溶量を以下のよ うにして求めた. $\mathrm{HNO}_{3} / \mathrm{HCl} / \mathrm{H}_{2} \mathrm{O}=1 / 3 / 10$ の混酸水 溶液により各試料の結合相のみを溶解・抽出し，乙の溶

* 1982年 4 月, 日本金属学会東京大会炕て一部発表, 炤和 57 年 6 月28日受理

** 東京大学工学部金属材料学科, $\mathrm{T} 113$ 東京都文京区本啣 7-3-1

*** 東京大学生産技術研究所, 1106 東京都港区六本木7-22-1

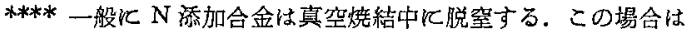
$\mathrm{TiC}_{0.7} \mathrm{~N}_{0.3}, \mathrm{TiC}_{0.5} \mathrm{~N}_{0.5}$ 中の $\mathrm{N}$ 量証最大約15\%減少し た. しかしこの脱窒は本論文の主旨飞影響しないので,

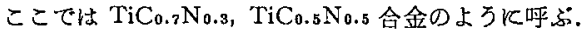




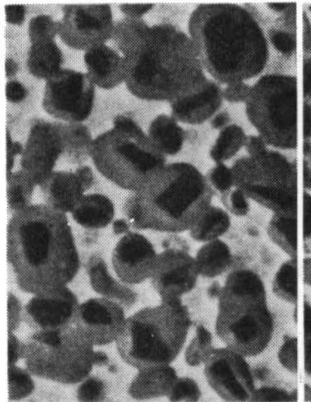

TiC alloy

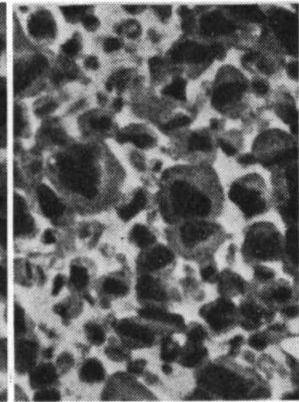

$\mathrm{TiC}_{0.7} \mathrm{~N}_{0.3}$ alloy

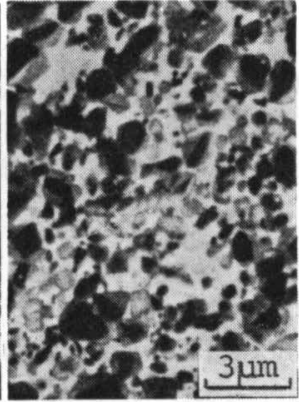

$\mathrm{TiC}_{0.5} \mathrm{~N}_{0.5}$ alloy

Photo. 1 SEM microstructures of TiC-Mo2 C-Ni, TiC $0.7 \mathrm{~N}_{0.3}-\mathrm{Mo}_{2} \mathrm{C}-\mathrm{Ni}$ and $\mathrm{TiC}_{0.5} \mathrm{~N}_{0.5}-\mathrm{Mo}_{2} \mathrm{C}-\mathrm{Ni}$ alloys (called $\mathrm{TiC}, \mathrm{TiC}_{0.7} \mathrm{~N}_{0.3}, \mathrm{TiC}_{0.5} \mathrm{~N}_{0.5}$ alloys, respectively) with medium carbon content. Sintered at $1693 \mathrm{~K}$ for $3.6 \mathrm{ks}$. The $\mathrm{Mo}_{2} \mathrm{C}$ and $\mathrm{Ni}$ contents are 19 and $23 \sim$ 24 mass $\%$, respectively.

液中の $\mathrm{Ni}$, Mo は原子吸光分析法により，Ti は ICP (Inductively Coupled Plasma) 発光分析法によって定量 分析した*. ことで，いずれの分析法においてあ，種々 の $\mathrm{Ni}, \mathrm{Ti}, \mathrm{Mo}$ 濃度溶液を用いて検量線を作製した．そ して高温機械的性質に及ぼす N 添加の影響を炭(窒)化物 粒度，結合相組成などとの関係で検討した。

\section{III 実 験 結 果}

Photo. 1 は, 中炭素の $\mathrm{TiC}, \mathrm{TiC}_{0.7} \mathrm{~N}_{0.3}, \mathrm{TiC}_{0.5} \mathrm{~N}_{0.5}$ 合 金 $\left(\mathrm{Mo}_{2} \mathrm{C}\right.$ 量はいずれあ19\%)の $\mathrm{SEM}$ 組織例である が, TiC 合金はもちろんのとと $\mathrm{TiC}_{0.7} \mathrm{~N}_{0.3}, \mathrm{TiC}_{0.5} \mathrm{~N}_{0.5}$ 合金の場合も，それぞれ炭化物または炭窒化物粒子は，

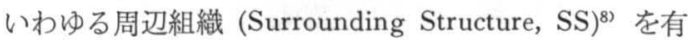
している. しかしN量が増加すると, SS の厚さが減少 し, 芯部 $\operatorname{Ti}(C, N)$ の平均 粒径も減少の傾向にあり, 炭窒化物は著しく微精となっている。 これは, 既報1) の 結果によると，主としてNの存在により粒成長が㧕えら れたためとして良いと思う. ここで, 写真を略したが, いずれの合金であ炭(窒)化物は高炭素, 高 $\mathrm{Mo}_{2} \mathrm{C}$ の合 金となるほど微粒となった

Fig. 1 には, $19 \% \mathrm{Mo}_{2} \mathrm{C}$ 含有の $\mathrm{TiC}, \mathrm{TiC}_{0.7} \mathrm{~N}_{0.3} お$ よび $\mathrm{TiC}_{0.5} \mathrm{~N}_{0.5}$ 合金の $\sigma_{m}$ におよぼす合金炭素量の影 響を示す，てれより $\sigma_{m}$ は高 $\mathrm{N}$ 合金ほど全体的に上昇す る.また，どの合金においても高炭素となるほど $\sigma_{m}$ は 上昇するが，その炭素量依存性は高 $\mathrm{N}$ 合金ほど小さくな

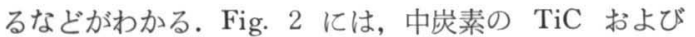
$\mathrm{TiC}_{0.7} \mathrm{~N}_{0.3}$ 合金について, $\sigma_{m}$ に及ぼす $\mathrm{Mo}_{2} \mathrm{C}$ 量の影響

* 従来, 結合相組成は粗粒合金の結合相を EPMA 分析する こととよって求められてきている(8)が, 本研究で用いた試 料は著しく微粒組織のため, 少なくとも EPMA 分析はで きない,むちろん, 粗粒合金を用いた EPMA 分析では, 結合相が非平衡状態となっている可能性があり ${ }^{10)}$, 問題が ある. よって, ここでは湿式分析を前提に, 結合相のみを 溶解する試薬を種々検討した結果, 上記のよろな混酸が最 適であることが見出された.
を示す．両合金とあ $\sigma_{m}$ は $\mathrm{Mo}_{2} \mathrm{C}$ 量の増加とともに上 昇するるが， $\mathrm{N}$ 添加合金は $\mathrm{Mo}_{2} \mathrm{C}$ 量によらず常に無添 加合金より高強度である.また $\mathrm{N}$ 添加合金の $\sigma_{m}$ は $\mathrm{Mo}_{2} \mathrm{C}$

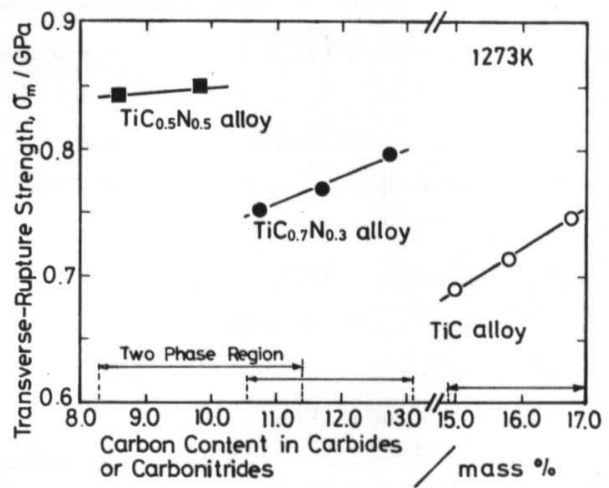

Fig. 1 Effect of carbon content on transverse-rupture strength $\left(o_{m}\right)$ of $\mathrm{TiC}, \mathrm{TiC}_{0.7} \mathrm{~N}_{0.3}$ and $\mathrm{TiC}_{0.5}$ $\mathrm{N}_{0.5}$ alloys with $19 \% \mathrm{Mo} 2 \mathrm{C}$. Test temperature is shown in the figure. The two phase region (ref. 2) of each alloy is also shown.

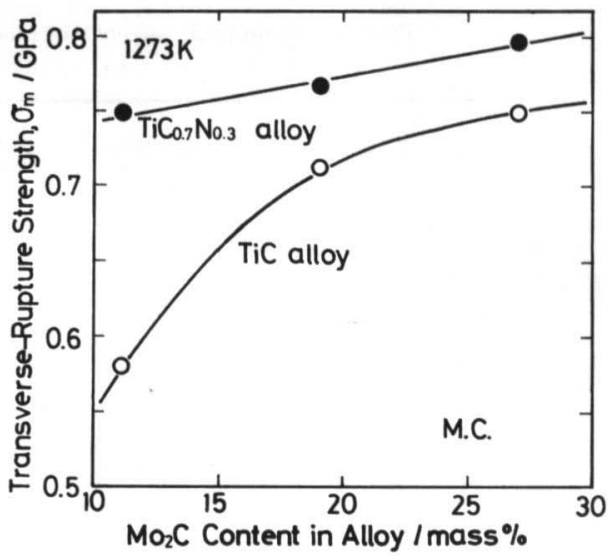

Fig. 2 Effect of $\mathrm{Mo}_{2} \mathrm{C}$ content on $\sigma_{m}$ of $\mathrm{TiC}$ and $\mathrm{TiC}_{0.7} \mathrm{~N}_{0.3}$ alloys with medium carbon (M. C.). 


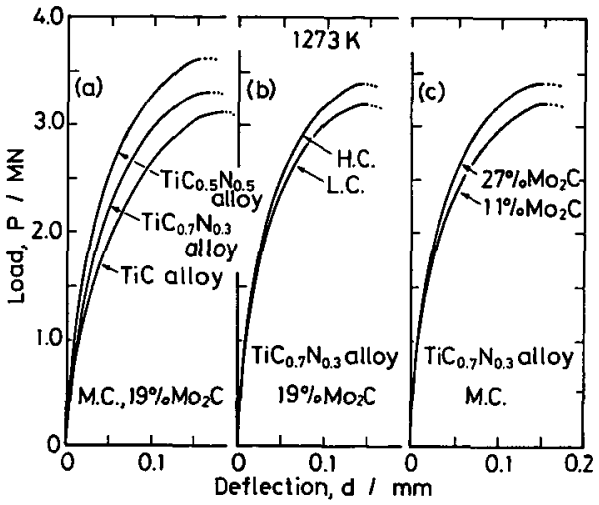

Fig. 3 Effects of nitrogen, carbon and $\mathrm{MO}_{2} \mathrm{C}$ contents on load-deflection curves. H.C.-high carbon; L.C.-low carbon. Crosshead speed, $8.3 \times 10^{-6}$ $\mathrm{m} / \mathrm{s}$.

量によってあまり影響されない。

Fig. $3(a \sim c)$ には， $P-d$ 曲線に及ぼす，それぞれN 量, 炭素量および $\mathrm{Mo}_{2} \mathrm{C}$ 量の影響を示したが, 曲線の 位置は，(a) によると高N合金活じ，(b) 亿よると高炭 素合金ほよ゙，(c) によると高 $\mathrm{Mo}_{2} \mathrm{C}$ 合金ほど高くなる。 そして変形しにくい（曲線の位置が高い）合金ほど， $\sigma_{m}$ が大となる，P d 曲線汇及ぼす $\mathrm{N}$ 量の影響は炭菜量, $\mathrm{Mo}_{2} \mathrm{C}$ 量のそれよりも大きい（市販の $\mathrm{TiC}$ 基合金にお ける $\mathrm{Mo}_{2} \mathrm{C}$ 量は結合相量にもよるが約 $20 \%$ 以下).な お，(b) の結果に対し，既報》で述べた TiN 添加合金は 高炭素となるほど，逆に変形しやすく，低強度となった が，乙れは TiN 添加合金の場合は本研究の場合上りむ 全体的に脱空量が多くなり ${ }^{2)}$, TiN 添加の高炭素合金で は脱空に基づくミクロ・ポアが生じやすかったためで あろう（高炭素合金では低炭素合金より屯脱窒量が多 $\left(4^{2)}\right)$.

つぎに，クリープ試験を行った．Fig. 4 は19\% $\mathrm{Mo}_{2} \mathrm{C}$

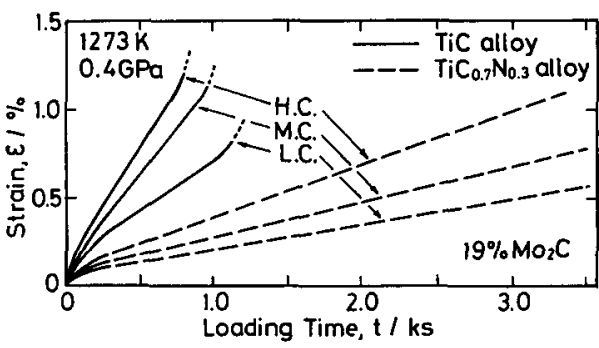

Fig. 4 Creep curves of $\mathrm{TiC}$ and $\mathrm{TiC}_{0.7} \mathrm{~N}_{0.3}$ alloys affected by carbon content.

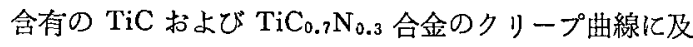
ばす炭素量の影響である．両合金ともクリープ変形は， 低炭素亡なるほど抑えられ，P-d 曲線の場合之傾向が逆 となる．また，N添加合金は全体的に著しく変形しにく い。なおここで, $\mathrm{TiC}_{0.5} \mathrm{~N}_{0.5}$ 合金の結果は略したが，そ の変形量は $\mathrm{TiC}_{0.7} \mathrm{~N}_{0.3}$ 合金の約 $1 / 2$ 程度となり,さ引に 変形しにくくなった. Fig. 5 には，両合金のクリープ曲 線に及ぼす $\mathrm{Mo}_{2} \mathrm{C}$ 量の影響を示す。両合金とも $\mathrm{Mo}_{2} \mathrm{C}$ 量が增加するほど变形しにくくなるが，Fig. 4 の場合之 同様，N添加合金の方が著しく変形が抑えられる。な拉 クリープ破断時間は，Fig. 4, 5 において，必ずしも明瞭 に示されていないが，N添加合金の方が $\mathrm{TiC}$ 合金に比 べて著しく大となり，両合金とも低炭素，高 $\mathrm{Mo}_{2} \mathrm{C}$ と なるほど大きくなる傾向にあった。

Table 1 には，炭素量と $\mathrm{Mo}_{2} \mathrm{C}$ 量の異なる $\mathrm{TiC}$ 合金, $\mathrm{TiC}_{0.7} \mathrm{~N}_{0.3}$ 合金について炭(窒)化物の粒度および結合相 組成を求めた結果を示す．粒度は炭素量， $\mathrm{Mo}_{2} \mathrm{C}$ 量に上 らずN添加合金に执いて著しく減少し，また両合金とも 高炭素加高 $\mathrm{Mo}_{2} \mathrm{C}$ となるほど減少する(既述). 他 方, 結合相組成をみると，Ti 固溶量は両合金とも低炭 素合金ほど增加し，高 $\mathrm{Mo}_{2} \mathrm{C}$ 合金ほど低下する。つぎ に Mo 固溶量は，低炭素合金ほよ゙，高 $\mathrm{Mo}_{2} \mathrm{C}$ 合金称よ゙

Table 1 Mean grain size of carbides (or carbonitrides) and binder phase composition

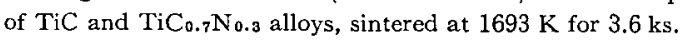

\begin{tabular}{|c|c|c|c|c|}
\hline \multirow{2}{*}{ Alloy composition } & \multirow{2}{*}{$\begin{array}{l}\text { Carbon } \\
\text { content }\end{array}$} & \multirow{2}{*}{ Grain size $/ \mu \mathrm{m}$} & \multicolumn{2}{|c|}{$\begin{array}{l}\mathrm{Ti}, \text { Mo contents in } \\
\text { binder phase/mass }\end{array}$} \\
\hline & & & $\mathrm{Ti}$ & Mo \\
\hline $\mathrm{TiC}-11$ g6 $\mathrm{Mo}_{2} \mathrm{C}-24$ g6 $\mathrm{Ni}$ & M. C. & 1.8 & 12.7 & 0.2 \\
\hline \multirow{3}{*}{$\mathrm{TiC}-19 \not 6 \mathrm{Mo}_{2} \mathrm{C}-24 \not 6 \mathrm{Ni}$} & H. C. & 1.1 & 4.9 & 0.3 \\
\hline & M. C. & 1.4 & 12.0 & 1.1 \\
\hline & L. C. & 1.5 & 16.3 & 1.8 \\
\hline TiC-27 $96 \mathrm{Mo}_{2} \mathrm{C}-24 \not 6 \mathrm{Ni}$ & M. C. & 1.2 & 11.9 & 2.1 \\
\hline $\mathrm{TiC}_{0.7} \mathrm{~N}_{0.3-11} \not 6 \mathrm{Mo}_{2} \mathrm{C}-24 \not 6 \mathrm{Ni}$ & M. C. & 1.1 & 10.6 & 3.4 \\
\hline \multirow{3}{*}{$\mathrm{TiC}_{0.7} \mathrm{~N}_{0.3}-1996 \mathrm{Mo}_{2} \mathrm{C}-24,96 \mathrm{Ni}$} & H. C. & 0.9 & 2.7 & 2.3 \\
\hline & M. C. & 1.0 & 8.4 & 5.9 \\
\hline & L. C. & 1.1 & 9.3 & 10.0 \\
\hline $\mathrm{TiC}_{0.7} \mathrm{~N}_{0.3}-27 \not 6 \mathrm{Mo} \mathrm{C}-24 \not 6 \mathrm{Ni}$ & M. C. & 0.9 & 5.7 & 8.2 \\
\hline
\end{tabular}




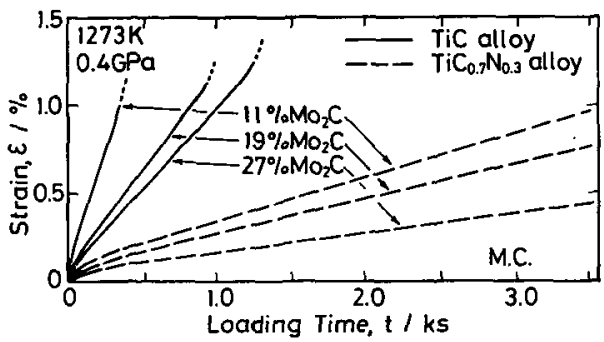

Fig. 5 Creep curves of $\mathrm{TiC}$ and $\mathrm{TiC}_{0.7} \mathrm{~N}_{0.3}$ alloys affected by $\mathrm{MO}_{\mathrm{O}} \mathrm{C}$ content.

增加するが，N添加による增加はとくに著しい，ところ で, 従来の EPMA 分析の結果 ${ }^{87,9)}$ 亿よる之，Ti 扣よび Mo 固溶量以及ぼす各要因の影響は，本結果之ほぼ同じ 傾向を示すが，EPMA 分析によるそれら固溶量の上限 值は本結果の値より屯小さく，本結果の約 $1 / 2$ 程度とな っている. てれは主として EPMA 分析における吸收補 正が十分でなかったためであるう。なお，結合相粒度 ${ }^{122}$ は表示しなかったが，高 $\mathrm{N}$, 低炭素, 高 $\mathrm{Mo}_{2} \mathrm{C}$ 合金ほ ど微粒となった。

\section{$\mathrm{N}$ 考察}

以上により， $\mathrm{TiC}-\mathrm{Mo}_{2} \mathrm{C}-\mathrm{Ni}$ 合金に $\mathrm{N}$ 添加した $\mathrm{Ti}(\mathrm{C}, \mathrm{N})-\mathrm{Mo}_{2} \mathrm{C}-\mathrm{Ni}$ 合金(遊離の $\mathrm{TiN}$ は組織中に存在し ない）は，P-d曲線とクリープ曲線のいずれにおいても $1273 \mathrm{~K}$ の高温で变形しにくくなり， $\sigma_{m}$ あクリープ強度

（破断時間）屯上舁するととが示された。すなわちサー メットの高温強度はN 添加によって確実敒良されるこ とがわかった。毛ちろんての場合，合金の高温強度はN 量一定下で，合金炭素量や $\mathrm{Mo}_{2} \mathrm{C}$ 量に応じてしかるべ く変化した。

まず, Fig. 1, 2 に示した $\sigma_{m}$, Fig. 3 亿示した $P-d$ 曲 線の結果を考元る．乙れらの結果によると，高N，高炭 素, 高 $\mathrm{Mo}_{2} \mathrm{C}$ 合金活ど变形が㧕えられ， $\alpha_{m}$ は上昇し た. そこで Table 1 をみると, そのような合金ほど炭 (窒)化物が微粒化し，N添加による微粒化はとくに著し いてよがわかる．そして結合相組成については，そのよ うな合金ほど，Ti 固溶量は常に減少し，一方，Mo 固 溶量は常に堌加するというととはない，他方，高温強度 之結合相粒度の関係については，粗粒合金ほど高温強度 が上昇することが知られている ${ }^{133}$ が，本研究では高N， 低炭素，高 $\mathrm{Mo}_{2} \mathrm{C}$ 合金活じ微粒之なった（既述）。す わち，高温強度が優れる合金ほど，結合相粒度が大とな るというととはない，以上述べた通りであるので，高N， 高炭素, 高 $\mathrm{Mo}_{2} \mathrm{C}$ 合金注ど機械的性質が優れたのは, そのような合金活ど炭(窒)化物が徽粒化したからと思わ れる.

そこで, 高, 低嵌素の 2 橿の $\mathrm{TiC}$ 合金について, 焼 結温度を $1623 \sim 1873 \mathrm{~K}$ の簌囲で変化させ，各種粒度の
試料を作り，それら試料の $P-d$ 曲線を調へ，Fig. 6 (a， b)をえた。 (a) は高岸素合金, (b) 㹥低孷素合金化ついて の結果である.図には $\mathrm{TiC}_{0.7} \mathrm{~N}_{0.3}$ 合金の結果 (Fig. 3 (b)）散示したが，乙れによるといずれの炭素量でも， 合金の変形は $\mathrm{N}$ 添加の有無によらず炭(窒)化物粒度の減 少とともに抑えられ，それととあに $\sigma_{m}$ が上昇する.す なわ方, 高 $\mathrm{N}$, 高炭素, 高 $\mathrm{Mo}_{2} \mathrm{C}$ 合金活ど高強度とな ったのは，岸(窒)化物の微柆化によるとして良い，付就 すると, Fig. 6 (a) と (b) を重社合わせると, 炭素量に よらず微粘合金ほど高強度になることか確かめられる.

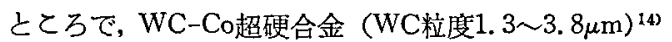
では約 $1083 \mathrm{~K}$ 以上の高温で WC が粗粒の合金ほど変 形しにくく，高強度となった．そしてての現象は粗粒合 金ほど，結合相が曲げ変形中に動的回復を起こしにくい （転位の上昇運動距離が大）ためとして理解された。 そ うすると, 本試料の場合, 微粒合金ほど変形しにくかっ たのは，その結合相が WC-Co 合金の結合相に比べ, 何らかの理由によって，1273 K でも動的回復をおてし にくいととを示す (後述).

つぎに，クリーブ曲線の結果を考える．Fig，4，5 亿 よると $\mathrm{N}$ 添加合金ほど, また低炭素, 高 $\mathrm{Mo}_{2} \mathrm{C}$ 合金ほ どクリープ変形が抑えられ，炭素量の影響は $P-d$ 曲線 の場合と逆になっている，故にクリープ変形は粒度の大 小と必ずしす対応しないととになるが，乙の点を粒度の 異なる TiC 合金について詳しく調べた結果は Fig. 7 (a，b) の通り之なった. こてで (a) は高岸素合金, (b) は低炭素合金の絬果であり，态力は $0.3 と 0.4 \mathrm{GPa}$ の 2 通りとした．これによると，高炭素の $\mathrm{TiC}$ 合金は，0.4 $\mathrm{GPa}$ では $P-d$ 曲線の場合之同様，微䊉合金の方が変形 しにくいが， $0.3 \mathrm{GPa}$ では逆に粗粒合金の方が変形し にくくなる，低炭素合金では，負荷芯力の高低によらず，

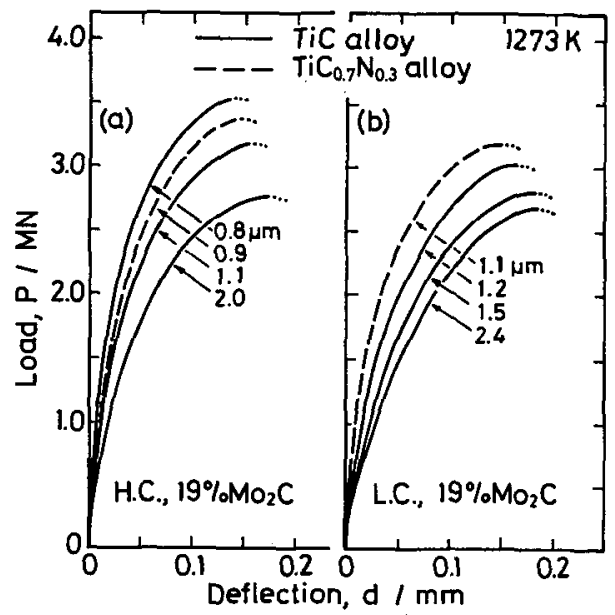

Fig. 6 Load-deflection curves of $\mathrm{TiC}$ alloys affected by carbide grain size. Curves of $\mathrm{TiC}_{0.7} \mathrm{~N}_{0.3}$ alloy shown in Fig. 3(b) are refered to. 


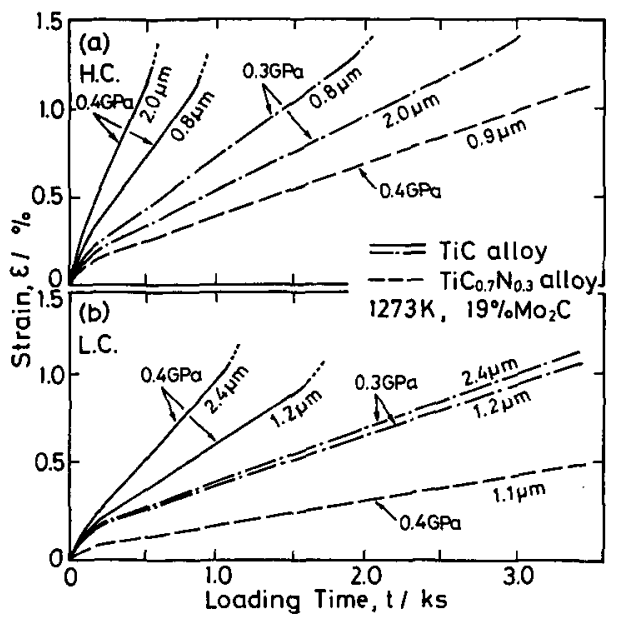

Fig. 7 Creep curves of TiC alloys affected by grain size. Curves of $\mathrm{TiC}_{0.7} \mathrm{No}_{0.3}$ alloy shown in Fig. 4 are refered to.

微粒合金の方が变形しにくいが，低応力下では粒度に基 つく変形の差が活とんどなくなる。他方， $\mathrm{TiC}_{0.7} \mathrm{~N}_{0.3}$ 合 金は，いずれの炭素量においても，ほぼ同一粒度の TiC 合金に比べ著しく変形しにくくなっている，以上の結果 加ら負荷応力が低く，同一歪量に達するまでの時間が長 くなる之，結合相の回復の影響が現われてくることがわ かる.そして，回復の程度は低炭素合金ほど，さらには N添加合金ほど小さくなることが示されよう。

そとで, Table 1 をみると, N添加合金ほどまた低 炭素合金ほど結合相中の Mo 固溶量が増加している， また，同一 $\mathrm{N}$ 量および炭素量の下では，高 $\mathrm{Mo}_{2} \mathrm{C}$ 合金 ほどMo 固溶量が多くなる。 そとで, Fig. 8 には, TiC, $\mathrm{TiC}_{0.7} \mathrm{~N}_{0.3}$ 合金䎲つて, Fig. 4, 5, 7 のクリープ曲線

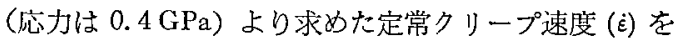
Mo 固溶量亡の関係で示したが, 両合金とも炭素量や

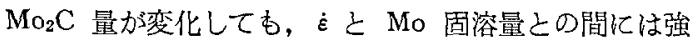
い相関のあると之がわかる。よって，本系合金のクリー

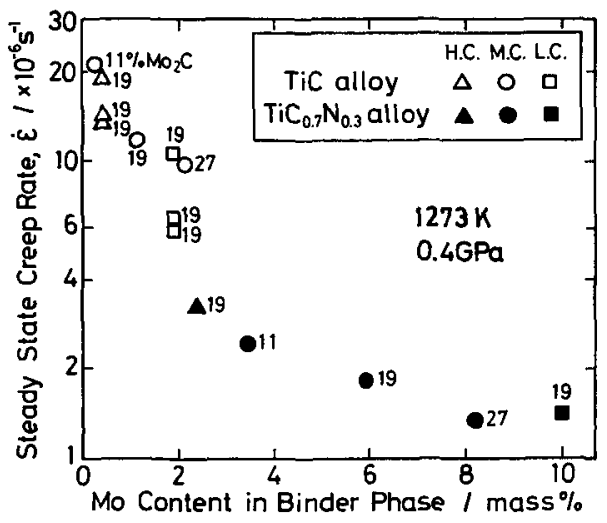

Fig. 8 Relation between creep rate and Mo content in binder phase in $\mathrm{TiC}$ and $\mathrm{TiC}_{0.7} \mathrm{~N}_{0.3 a l l o y s .}$
プ変形がN添加などによって抑えられたのは，結合相中 にNが固溶するからら出ではなく，Mo がより多く固溶 するた如に結合相の動的回復が起こりにくくなったこと に原因があるのではないかと思われる。これは Ni 基耐 熱合金の高温強度に及恬す固溶元秦の影響は，Ti は有 効でないが，Mo，W などはある戛までの固溶において 著效を示すととが知られているからである ${ }^{(5), 16)}$. Mo 固 溶の効果をこのように捉えると， $P-d$ 曲線に抢いて微粒 合金ほど变形しにくかったととについても，一忘の説明 が可能となろう。

しかしててで，本系合金の高温強度関する機構が十 分に明らかになったわけではない，現象論的には極めて 興味ある結果が兄られたと思うが，その機構については WC-Co 合金との比較に捺いて今後詳しく検討したい.

\section{$\mathrm{V}$ 結 言}

炭素量を变化させた $\mathrm{TiC}-(11 \sim 27) \% \mathrm{Mo}_{2} \mathrm{C}-(24 \sim 25) \%$

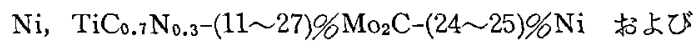
$\mathrm{TiC}_{0.5} \mathrm{~N}_{0.5}-19 \% \mathrm{Mo}_{2} \mathrm{C}-23 \% \mathrm{Ni}$ 合金について, 真空中, $1273 \mathrm{~K}$ に杉ける抗折力, 荷重 $(P)$-たわみ $(d)$ 曲線扔よ びクリープ曲線などを求めた，そして， $\mathrm{TiC}-\mathrm{Mo}_{2} \mathrm{C}-\mathrm{Ni}$ 合金の高温機械的性質に及㜔す素 $(\mathrm{N})$ 添加の影響 $(て$ の場合は合金中に TiN の分散相はない)を詳しく検討 し, 以下の結果を得た。

1）高 $\mathrm{N}$, 高炭素, 高 $\mathrm{MO}_{2} \mathrm{C}$ 合金活ど, $P-d$ 曲線に招 ける変形が㧩えられ，またそのような合金ほど高温抗折 力の優れることがわかった。そしてそのような合金活ど 炭(空)化物の粒度が減少した。この粒度依存性は WCCo 超硬合金の場合と逆であった.

2）クリープ变形はN添加によって著しく抑えられ，ま た低炭素，高 $\mathrm{Mo}_{2} \mathrm{C}$ 合金活ど抑えられ，乙の上うな合 金はクリープ強度の優れるてとが示された．そして，そ のような合金ほど結合相中の Mo 固溶量が上昇し， $\mathrm{TiC}_{0.7} \mathrm{~N}_{0.3}-19 \% \mathrm{Mo}_{2} \mathrm{C}-24 \% \mathrm{Ni}$ 合金代おいては，約10\% にあ達したすすなわち合金のクリープ変形が抑えられる のは，結合相中への Mo の固溶により結合相の動的回 復が抑えられるためと考えられた。微粒合金活ど $P-d$ 曲線に招ける変形が抑えられたのも，同様と考えられた ただし，これらの詳しい機構は後報で検討する。

3）以上により， $\mathrm{TiC}-\mathrm{Mo}_{2} \mathrm{C}-\mathrm{Ni}$ 合金の高温変形（强 度）に及ぼす $\mathrm{N}$ 量, 炭素量, $\mathrm{Mo}_{2} \mathrm{C}$ 量さらには炭(窒)化 物垃度の影響が明らかになったが，とりわけN添加は合 金の高温変形を著しく排え，抗折力，クリープ強度を大 幅に改善することが明確になった。

最後に，本研究の結合相組成分析に関し，種々御配虑 を願った日本鉱業蛛中央研究所の中村靖分析試験室長な らびに関係各位に澘く謝意を表する。 


\section{文献}

1）鈴木，林，山本，李: 粉体招よび粉末治金，23 (1976), 224.

2）鈴木，林，久保，松原：粉体执よび粉末冶金，28 (1981)， 147.

3）鈴木，林，久保：粉体括よび粉末治金， 27 (1980)，266.

4) 鈴木, 林, 久保, 靳: 粉体括よび粉末治金, 28 (1981), 67.

5) D. Moskowitz and M. Humenik: Modern Developments in Powder Metallurgy, vol. 14, edited by $\mathrm{H} . \mathrm{H}$. Hausner et al., Plenum Press, N.Y., (1980), 307.
6）鈴木，松原，林：日本金属学会誌，46 (1982), 651 .

7) R. L. Fullman: J. Metals, 5 (1953), 447.

8）鈴木，林，寺田：日本金属学会誌，35 (1971), 936.

9) 西垚, 土井：粉体打よび粉末炲金, 27 (1980), 130.

10）林, 鈴木, 川勝：日本金属学会誌, 32 (1968), 997.

11）鈴木，林，寺田：日本金属学会誌，36 (1972)，514.

12）鈴木，林，寺田，福田：粉体および粉末治金，21 (1974)， 51.

13）鈴木，林，久保：粉体怙よび粉末绐金，26 (1979)，192.

14）鈴木，林，谷口，松原：日本金属学会誌，44(1980), 1210.

15) 須藤：材料, 21 (1972), 159.

16）藤田，柴田：日本金属学会報，16 (1977), 231 .

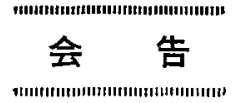

\section{第 3 回電子材料研究討論会 講演募集}

\author{
主 催：窒業協会 \\ 協 賛: 粉体粉末治金協会 他 \\ 日 時: 10月14日（金） \\ 会 場 : 東京大学工学部 5 号館 (東京都文京区本郷) \\ テーマ：エレクトロニク・セラミックスの基碟科学
}

講演時間 : 講演 25 分, 討論 10 分（講演申远数により時間 を調整する場合があります。）

講演申込：官製はがきに，題目，発表者所属・氏名（講 演者に○印)，100字程度の概要，連絡者氏名, 住所, 電話番号䘮明記のうえ, 下記宛お申迂み 下さい，講演要旨は約1300字詰の所定の原稿用 紙 2 枚に書いていただき，オフセット印刷いた します。

申込締切：7月 9 日（土）

申 込 先: 干113 東京都文京区本郷7一-3-1 東京大学 工学部 工業化学科 柳田研究室 宮山 勝 電話：(03)812--21111(内線7198)

\section{新入特別会員}

（昭和58年 4 月現在）

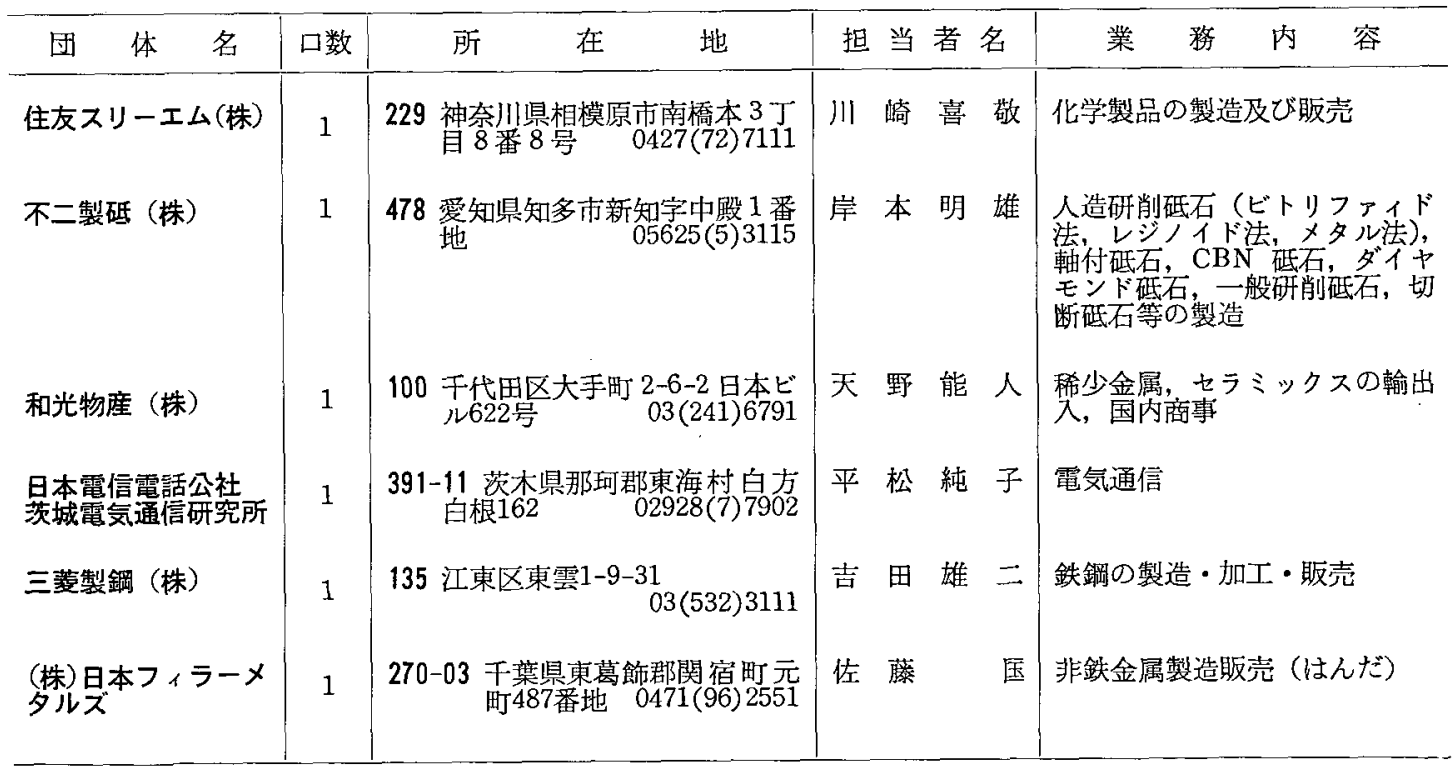

